\title{
SISTEM INFORMASI REPOSITORI SKRIPSI BERBASIS WEB PADA STMIK SYAIKH ZAINUDDIN NW ANJANI
}

\author{
Lalu Puji Indra Kharisma ${ }^{1}$, Muh. Fahrurrozi ${ }^{2}$, Khairunnazi ${ }^{3)}$ \\ ${ }^{1,2,3)}$ STMIK Syaikh Zainuddin NW \\ Jln. Raya Mataram - Lb Lombok KM 49 Desa Anjani Lombok Timur \\ e-mail: 1alupujii@gmail.com ${ }^{1)}$,f4.rozi@gmail.com ${ }^{2)}$, m4sterlenk@gmail.com ${ }^{3)}$
}

\begin{abstract}
Sistem Informasi Repository ini merupakan ide yang muncul untuk membantu instansi mengelola pengarsipan skripsi yang sebelumnya masih dilakukan secara konvensional dengan cara mengumpulkan hasil jilidan skripsi (hardcopy) dan CD yang berisikan file-file skripsi beserta source code program yang dibuat (softcopy) menjadi sebuah sistem digital yang baru dan modern. Sistem Informasi Repository merupakan sistem yang diharapkan dapat membantu Sekolah Tinggi Manajemen Informatika dan Komputer (STMIK) Syaikh Zainuddin NW Anjani untuk mengatur pengarsipan data-data skripsi yang telah dikerjakan oleh para mahasiswanya menjadi lebih rapi, aman dan mudah untuk dikelola. Sistem informasi repository dikembangkan menggunakan model proses pengembangan perangkat lunak waterfall dan pemodelan analisis berorientasi objek, lalu diimplementasikan menggunakan bahasa pemrograman Codeigniter yaitu salah satu framework PHP. Hasil penelitian ini adalah sebuah sistem repository skripsi berbasis website yang dapat mengarsipkan data skripsi mahasiswa dan dapat digunakan pula untuk melakukan pencarian dan menampilkan data skripsi yang ada melalui interface admin maupun pengguna dalam hal ini mahasiswa.
\end{abstract}

Kata Kunci:Sistem Informasi Repositori, Skripsi, Codeigneter.

\begin{abstract}
ABSTRAK
This Repository Information System is an idea that appears to help agencies manage thesis archiving that was previously still done conventionally by collecting the results of thesis binding (hardcopy) and CD containing thesis files along with the source code of the program that was made (softcopy) into a digital system new and modern. Repository Information System is a system that is expected to help the School of Information and Computer Management (STMIK) Shaykh Zainuddin NW Anjani to organize the archiving of thesis data that has been done by students to be neater, safer and easier to manage. The repository information system was developed using the waterfall software development process model and object oriented analysis modeling, then implemented using the Codeigniter programming language, one of the PHP frameworks. The result of this study is a website-based thesis repository system that can archive student thesis data and can also be used to search and display existing thesis data through the admin or user interface in this case students.
\end{abstract}

Keywords : Repository Information System,Thesis, Codeigniter

\section{PENDAhUluan}

$\mathrm{P}$ erpustakaan perguruan tinggi adalah perpustakaan yang melayani para mahasiswa, dosen, dan karyawan suatu perguruan tinggi tertentu (akademik, universitas, institut, sekolah tinggi, politeknik). Koleksi suatu perpustakaan perguruan tinggi tidak hanya terbatas pada buku-buku teks yang diperlukan untuk menunjang kegiatan belajar mengajar saja, tetapi juga buku-buku dan jurnal-jurnal ilmiah yang diperlukan untuk menunjang penelitian para dosen dan mahasiswa [1].

Repository adalah atau "Simpanan Kelembagaan" merujuk ke sebuah kegiatan menghimpun dan melestarikan koleksi digital yang merupakan hasil karya intelektual dari sebuah komunitas tertentu[2], menurut Lynch $^{[3]}$, repository adalah satu set layanan yang ditawarkan universitas kepada anggota masyarakat untuk pengelolaan dan penyebaran materi digital yang dibuat oleh lembaga atau masyarakat.

Istilah Repository berkembang seiring munculnya istilah perpustakaan digital pada awal tahun 1990-an yang berujuk pada kegiatan menghimpun melestarikan koleksi digital yang merupakan hasil karya intelektual dari sebuah komunitas. Berawal dari kegiatan komunitas suatu Universitas Southampton di Inggris, mengumpulkan berbagai hasil karya secara lokal terutama dalam bentuk digital. Program yang menghimpun database untuk pertama kali oleh Eprint yang dikembangkan oleh Universitas tersebut.

Sekolah Tinggi Manajement dan Komputer 
(STMIK) Syaikh Zainuddin NW Anjani saat ini belum maksimal dalam pelayanan mengenai pengumpulan dan publikasi skripsi. Mahasiswa yang telah selesai melaksanakan ujian akhir harus menyerahkan hasilnya dalam bentuk skripsi yang telah dijilid (hardcopy) dan juga $\mathrm{CD}$ yang berisikan file-file skripsi dan source code program yang dibuat (softcopy) kepada staf Prodi dan staf perpustakaan untuk didata dan diarsipkan. Setiap tahun STMIK Syaikh Zainuddin NW Anjani menghasilkan cukup banyak lulusan, sehingga jumlah skripsi yang diserahkan dan harus didata juga semakin banyak.

Proses tersebut masih dilakukan dengan cara konvensional yaitu mahasiswa harus menyerahkan file skripsi menggunakan CD. Selain itu, apabila ada mahasiswa yang membutuhkan skripsi yg sudah ada, maka mereka harus melakukan pencarian satu persatu pada arsip perpustakaan. Masalah lainnya yang timbul jika secara kebetulan skripsi yang dicari sedang dipinjam oleh mahasiswa lainnya, maka mahasiswa harus menunggu mahasiswa yang lain tersebut mengembalikan skripsi yang dipinjamnya. Serta karya akhir mahasiswa lebih banyak dikelola oleh, dosen hanya bisa mengontrol dan mengira apakah tema penelitian yang telah lalu sama dengan penelitian yang sekarang dilakukan dalam hal ini dapat juga menunjang akreditasi kampus.

Karena itulah dibutuhkan sebuah sistem yang dapat membantu pihak akademi menjalankan tugas pendataan skripsi dan juga memudahkan mahasiswa dalam melakukan pencarian skripsi yang relevan dan dibutuhkan dalam proses kegiatan penyusunan karya ilmiah. Berdasarkan latar belakang tersebut, penulis mengangkat penelitian dengan judul "Sistem Informasi Repository Skripsi pada Sekolah Tinggi Manajemen Dan Komputer Syaikh Zainuddin NW Anjani ". Dengan adanya penelitian ini diharapkan dapat membantu meningkatkan pelayanan pada Sekolah Tinggi Manajemen Dan Komputer Syaikh Zainuddin NW Anjani khususnya dalam hal pelayanan skripsi. Diharapkan dari hasil penelitian sistem informasi Repository skripsi ini adanya sistem berbasis komputer yang akan membantu memudahkan pelayanan dalam hal keperpustakaan skripsi khususnya bagi mahasiswa STMIK Syaikh Zainuddin NW Anajni, sehingga akan menjadikan STMIK Syaikh Zainuddin NW Anjani semakin baik dan semakin maju.

\section{STUDI PUSTAKA}

Studi pustaka adalah salah satu aktivitas untuk meninjau kembali literature yang telah dipublisasikan dari hasil penelitian yang serupa yang telah dibuat oleh bebrapa peneliti sebelumnya. Adapaun bebrapa studi pustaka yang digunakan dalam penelitian ini adalah sebagai berikut.

Penelitian mengenai repository skripsi dilakukan oleh hidayat [3] dengan judul System repository skripsi pada FTKI Universitas Mulawarman. Aplikasi
Dikembangkan menggunakan model proses pengembangan perangkat lunak waterfall dan pemodelan analisis berorientasi objek, lalu diimplementasikan menggunakan bahasa pemrograman PHP. Hasil penelitian ini adalah sebuah sistem repository skripsi berbasis website yang dapat mengarsipkan data skripsi mahasiswa dan dapat digunakan pula untuk melakukan pencarian dan menampilkan data skripsi yang ada melalui interface admin maupun pengguna dalam hal ini mahasiswa[4].

Hal serupa juga dilakukan oleh Ainun[4] dengan judul aplikasi mobile repository yang bertujuan mempermudah mahasiswa mencari refrensi skripsi alumni secara online pada STMIK IBBI. Penelitian ini bertujuan untuk merancang sistem untuk mempermudah mahasiswa mencari referensi skripsi alumni secara online. Pengembangan perangkat lunak menggunakan metode waterfall, pada tahap analisa dan perancangan sistem usulan penelitian menggunakan pemodelan Unified Modeling Language $(U M L)[5]$.

\section{METODE PENELITIAN}

\section{A. Metodologi Penelitian}

Kegiatan yang dilakukan dalam penelitian adalah:

1. Akuisisi Pengetahuan

a. Studi literatur : mempelajari literatureliteratur yang berhubungan dengan penelitian yang dilakukan yaitu terkait dengan Sistem Informasi dan Repositori. Literatur diperoleh dari berbagai sumber antara lain dari jurnal ilmiah, laporan penelitian, buku dan sumber lainnya yang memiliki hubungan dengan penelitian yang dilakukan.

b. Wawancara : wawancara dilakuakan dengang pihak institusi terkai yaitu dengan Bapak H. Rasyidin selaku Bagian perpustakaan STMIK SZ NW Anjani.

2. Perancangan Sistem

Fokus pada desain sistem yang akan dibangun meliputi rancangan UML (Unified Modeling Language) yang terdiri dari : Use Case Diagram, Activity Diagram, rancangan basis data, rancangan antarmuka aplikasi

3. Implementasi

Pada tahapan ini deskripsi perancangan diterjemahkan menggunakan sa;ah satu framework PHP yaitu Codeignniter.

4. Pengujian

Pada tahap ini pengujian terhadap sistem yang telah dikembangkan dengan cara menguplod beberapa laporan skripsi mahasiswa dengan tipe file pdf, kemudian mahasiwa atau user dapat mencari data laporan skripsi yang sudah ada pada sistem dan dapat mengunduhnya. 
Kharisma, Fahrurrozi Dan Khairunnazi — Sistem Informasi Repositori Skripsi Berbasis Web Pada STMIK Syaikh Zainuddin NW Anjani

\section{B. Perancangan Sistem}

\section{1) Use Case Diagram}

Perancangan awal dibuat kedalam bentuk use case diagram untuk menjelaskan gambaran sistem dan actor yang terlibat secara keseluruhan. Use case diagram sistem dapat di lihat pada Gambar 1.

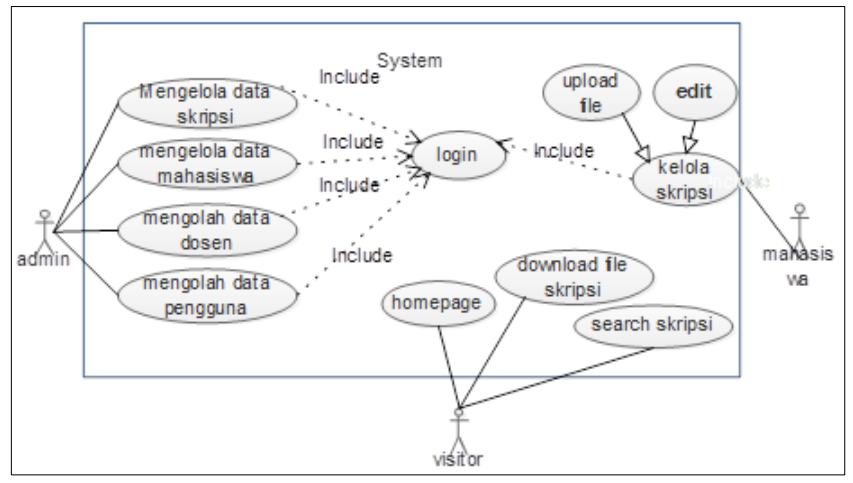

Gambar 1. Use Case Diagram

Dari use case diatas dapat dilihat beberapa actor yang terlibat pada sitem informassi repository skripsi yaitu Admin, Mahasiswa dan User umum dimana masing - masing actor memiliki aktivitas sebagai berikut :

Admin dapat mengelola data skripsi,data mahasiswa, data pengguna dan data dosen, Kemudian Mahasiswa dapat mengupload file skripsi dan Visitor dapat melihat dan mencari judul skripsi serta download file skripsi.

\section{2) Activity Diagram}

Dalam perancangan sistem ini, penulis menggambarkan beberapa activity diagram yang ada pada perancangan sistem.

1. Activity diagram login

Aktifitas yang menggambarklan proses login dapat dilihat pada gambar 2 .

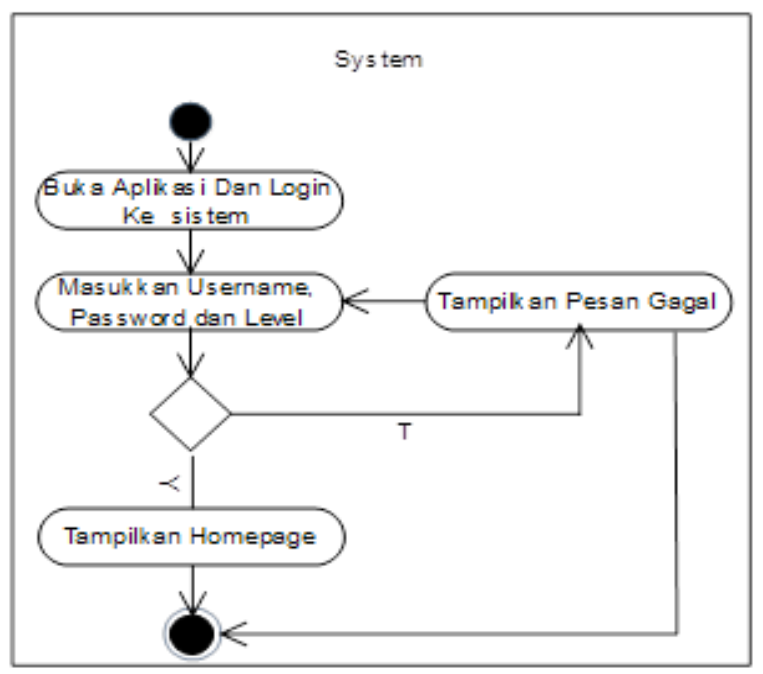

Gambar 2. Activity diagram Login

\section{Activity diagram Admin}

Aktifitas yang menggambarkan admin dalam proses menjalankan aplikasi dapat dilihat pada gambar 3 .

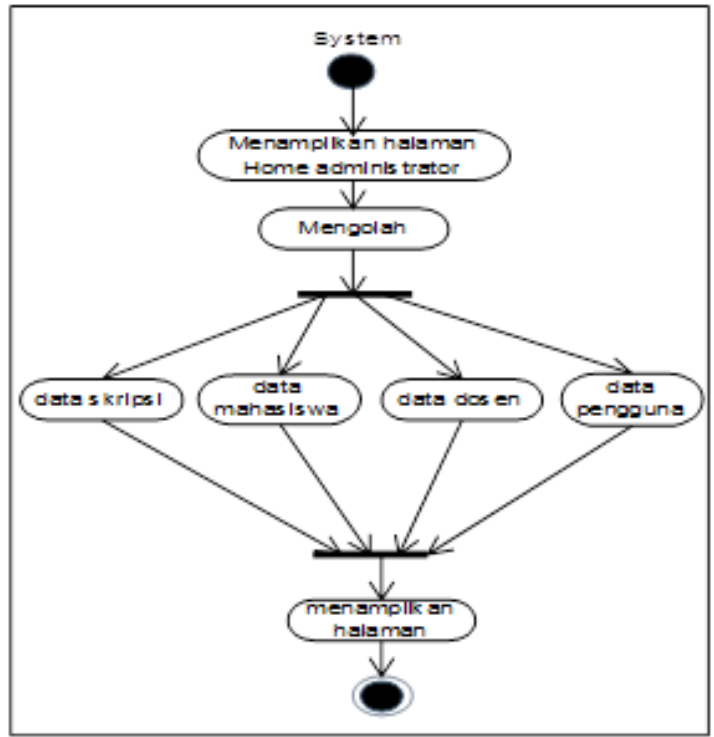

Gambar 3. Activity Diagram Admin

3. Activity Diagram Mahasiswa

Aktifitas yang menggambarkan mahasiswa dalam proses menjalankan aplikasi dapat dlihat pada gamabr 4 .

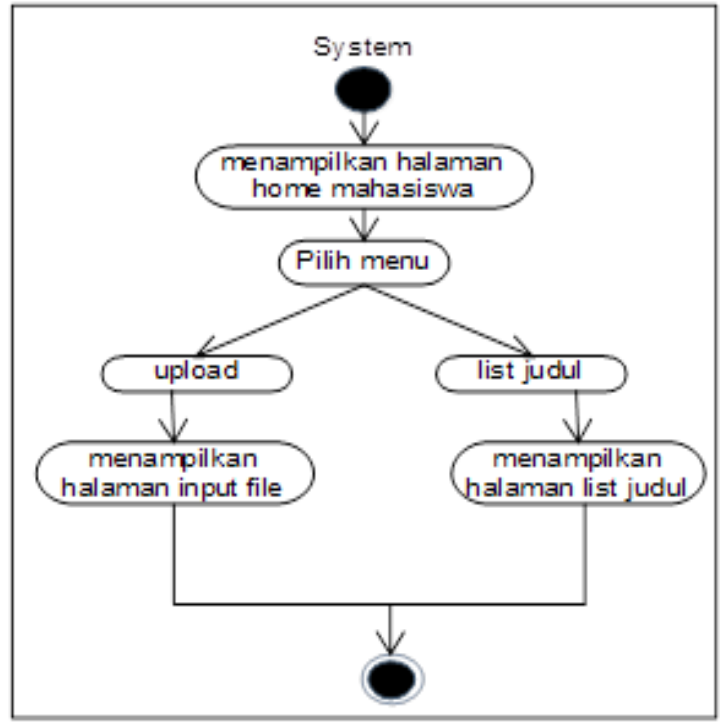

Gambar 4. Activity Diagram Mahasiswa

\section{Activity Diagram Visitor}

Aktifitas yang menggambarkan visitor dalam menjalankan aplikasi dapat dilihat pada gambar 5. 


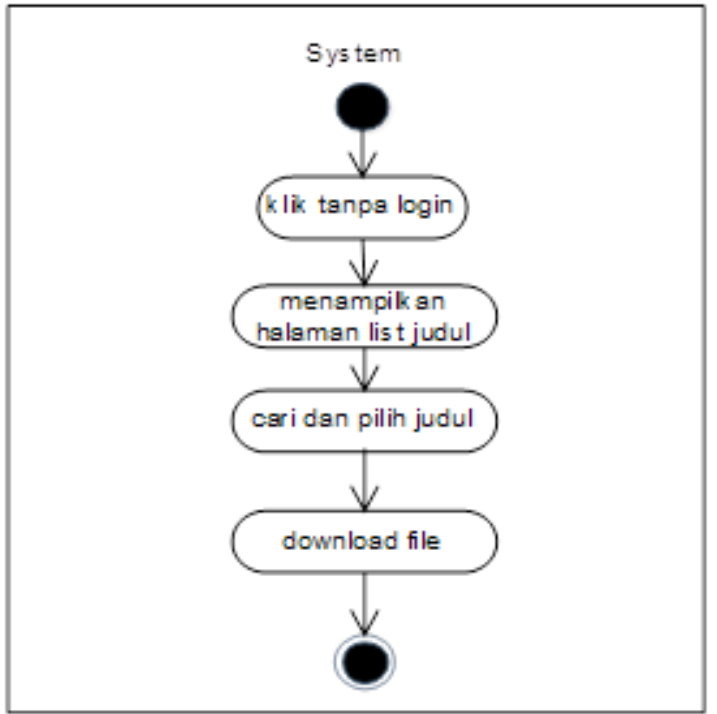

Gambar 5. Activity Diagram Visitor

\section{3) Class Diagram}

Class Diagram digunakan menampilkan beberapa kelas serta paket yang ada dalam system/perangkat lunak. Class Diagram sistem informasi repository dapat dilihat pada gambar 6 .

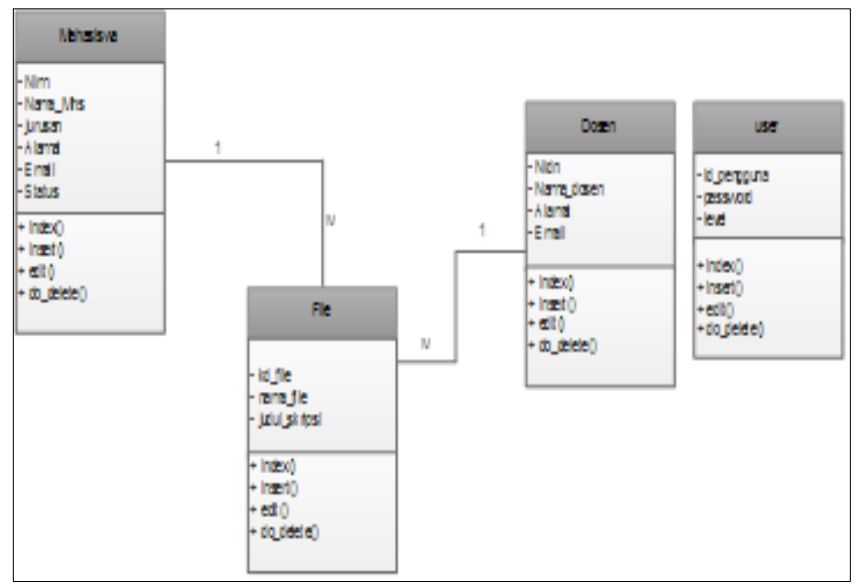

Gambar 6. Class diagram sistem informasi repositori

\section{HASIL DAN PEMBAHASAN}

Tujuan dari penelitian ini adalah untuk membangun Sistem Informasi Repository Skripsi pada STMIK Syaikh Zainuddin NW Anjani Berbasis Web. Sehingga memberi kemudahan dalam mencari dan menyimpan hasil karya ilmiah dan laporan penelitian.

\section{A. Tampilan Halaman Login}

Halaman login akan tampil pertama kali jika aplikasi di jalankan Admin/Operator hanya memasukkan nama dan sandi. Jika nama dan sandi benar maka halaman home administrator akan aktif. Selain itu juga admin bisa mengubah nama dan sandi pada menu pelayanan admin seperti terlihat pada gambar 7 .

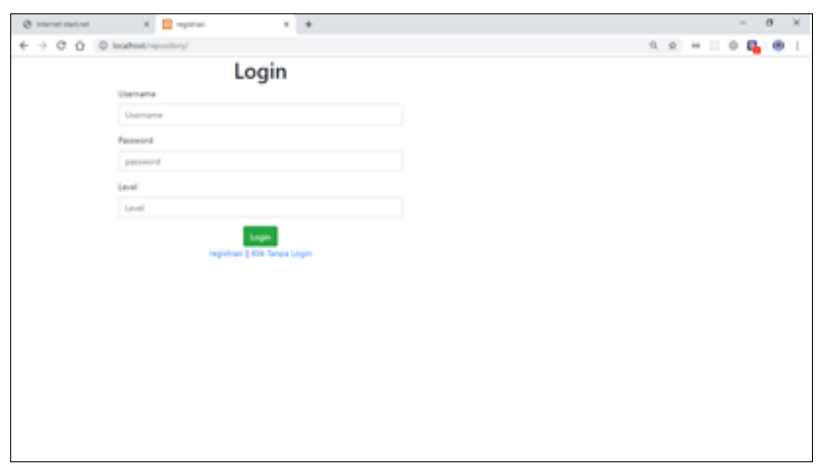

Gambar 7. Tampilan Halaman Login

\section{B. Tampilan Halaman Home Administrator}

Halaman home akan tampil jika admin berhasil login. Pada halaman ini ada beberapa menu yaitu skripsi, mahasiswa, dosen dan pengguna. Admin dapat mengelola data pada setiap menu seperti terlihat pada gambar 8 .

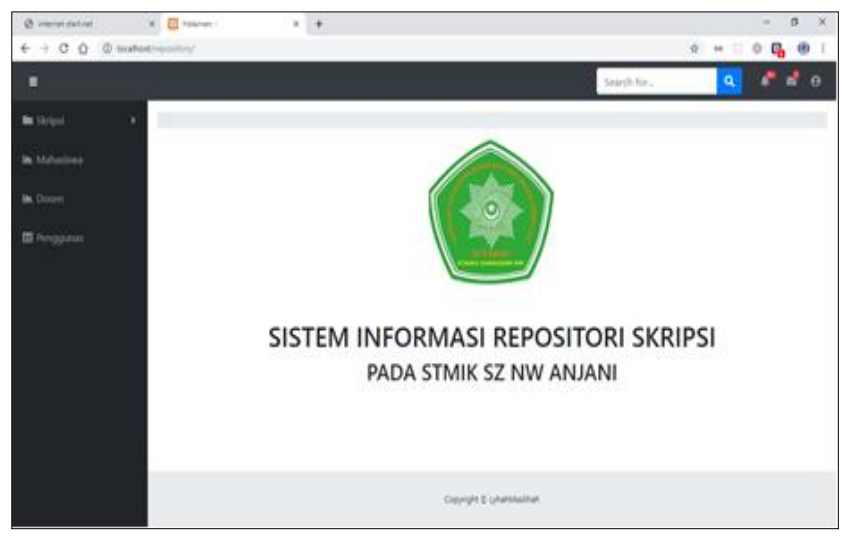

Gambar 8. Tampilan Halaman Home Administrator

\section{Tampilan Halaman Skripsi}

Halaman Skripsi berisi list skripsi, pada halaman ini admin dapat mengelola data skripsi yaitu tambah, ubah dan hapus data seperti terlihat pada gambar 9 .

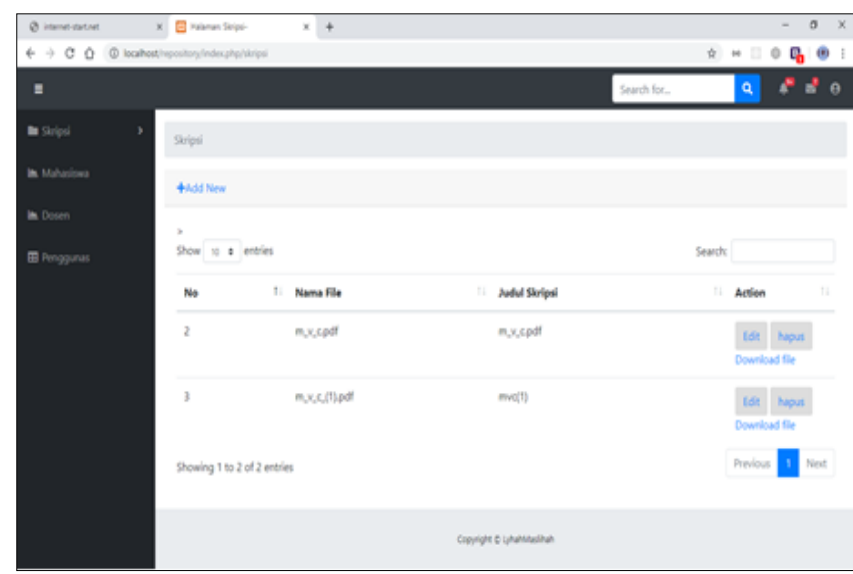

Gambar 9. Tampilan Halaman Skripsi

\section{Tampilan Data Mahasiswa}

Halaman data mahasiswa berisi list data mahasiswa, pada halaman ini admin dapat mengelola data mahasiswa yaitu tambah, ubah dan hapus data seperti 
terlihat pada gambar 10 .

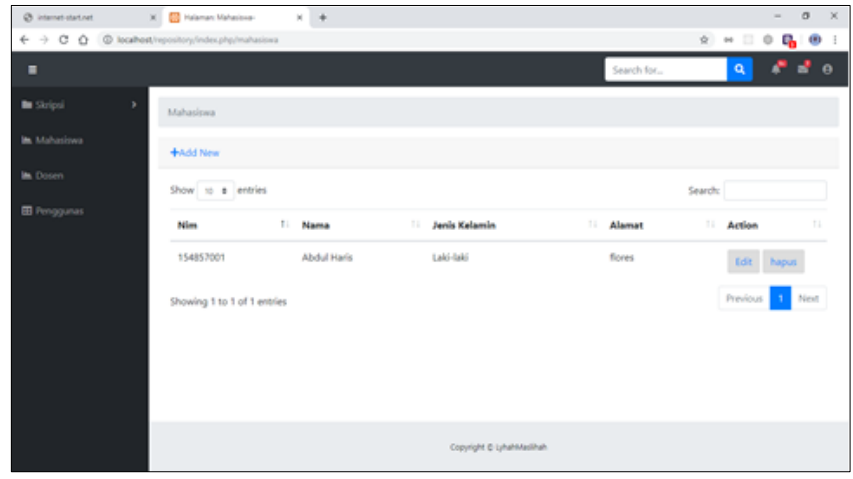

Gambar 10. Tampilan data Mahasiswa

\section{E. Tampilan Halaman Data Dosen}

Halaman data dosen berisi list data dosen, pada halaman ini admin dapat mengelola data dosen yaitu tambah, ubah dan hapus data seperti terlihat pada gambar 11.

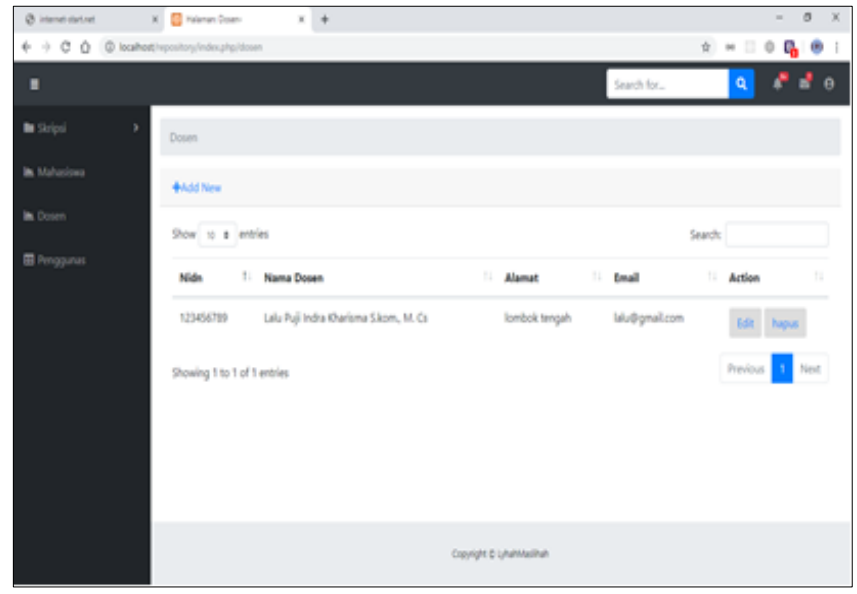

Gambar 11. Tampilan Halaman Dosen

\section{F. Tampilan Halaman Data Pengguna}

Halaman data pengguna berisi list data pengguna atau users, pada halaman ini admin dapat mengelola data pengguna yaitu tambah, ubah dan hapus data seperti terlihat pada gambar 12 .

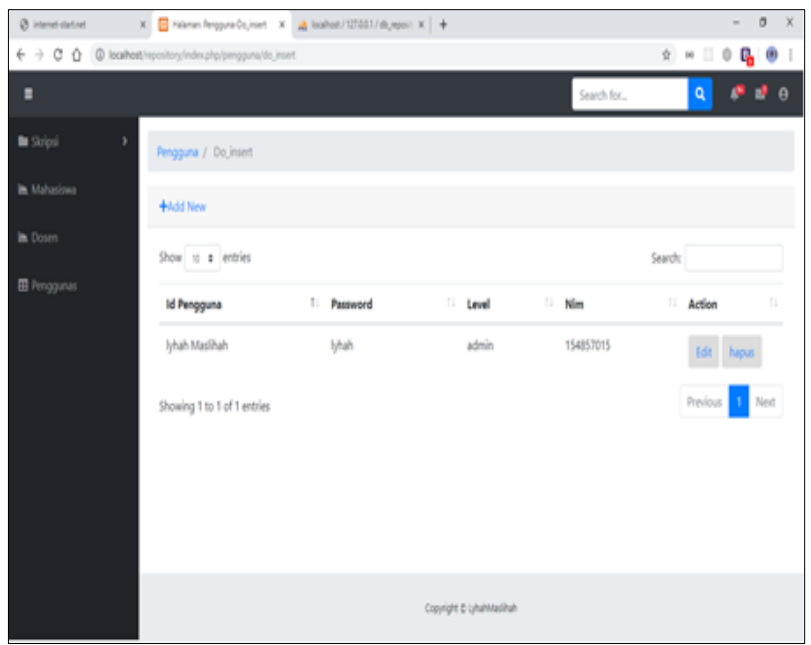

Gambar 12. Tampilan Halaman Data Pengguna

\section{nuddin NW Anjani}

\section{G. Tampilan Uploud Skripsi}

Halaman Upload skripsi berisi form pengisian data skripsi, pada halaman ini admin dapat mengeloladata skripsi yaitu tambah data seperti terlihat pada gambar 13.

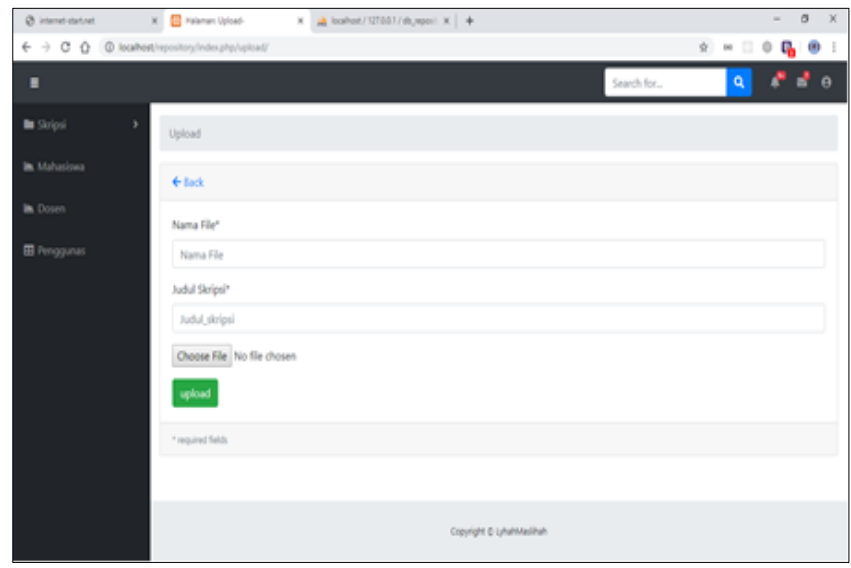

Gambar 13. Tampilan Uploud Skripsi

\section{H. Tampilan Input Data Mahasiswa}

Halaman input data mahasiswa berisi form pengisian data mahasiswa, pada halaman ini admin dapat mengelola data mahasiswa yaitu tambah data seperti terlihat pada gambar 14.

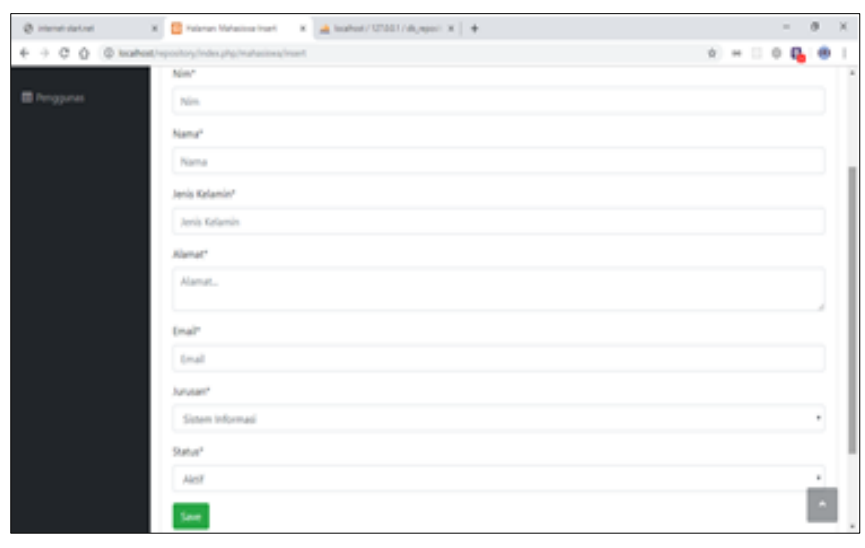

Gambar 14. Tampilan Input Data Mahasiswa

\section{Tampilan Input Data Dosen}

Halaman input data dosen berisi form pengisian data dosen, pada halaman ini admin dapat mengolah data dosen yaitu tambah data seperti terlihat pada gambar 15 . 


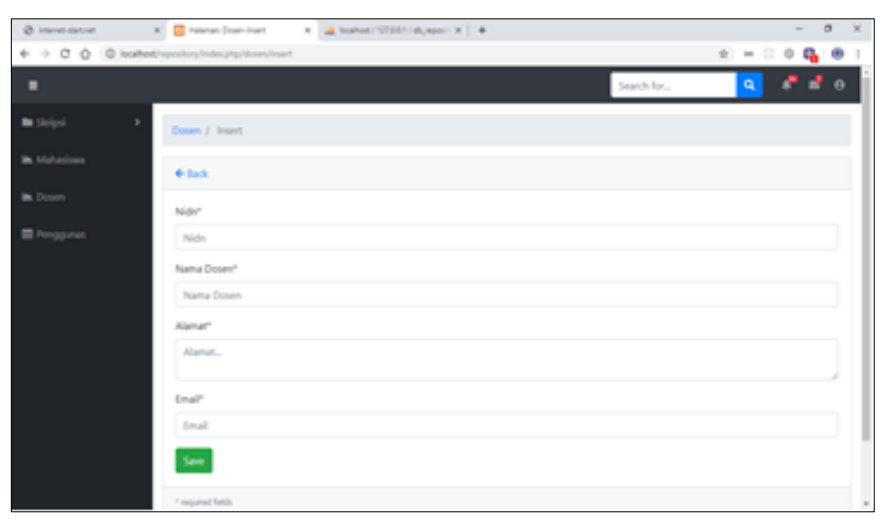

Gambar 15. Tampilan Input Data Dosen

\section{J. Tampilan Input data Pengguna}

Halaman input data pengguna berisi form pengisian data pengguna, pada halaman ini admin dapat mengelola data pengguna yaitu tambah data seperti terlihat pada gambar 16.

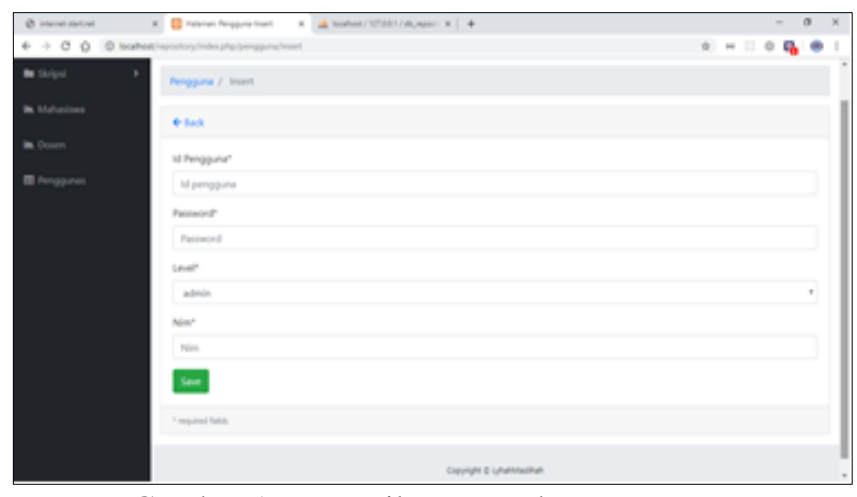

Gambar 16. Tampilan Input data Pengguna

\section{K. Tampilan halaman Download}

Halaman download file skripsi berisi list judul skripsi dan link download, pada halaman ini admin maupun pengguna dapat mendownload file skripsi seperti terlihat pada gambar 17 .

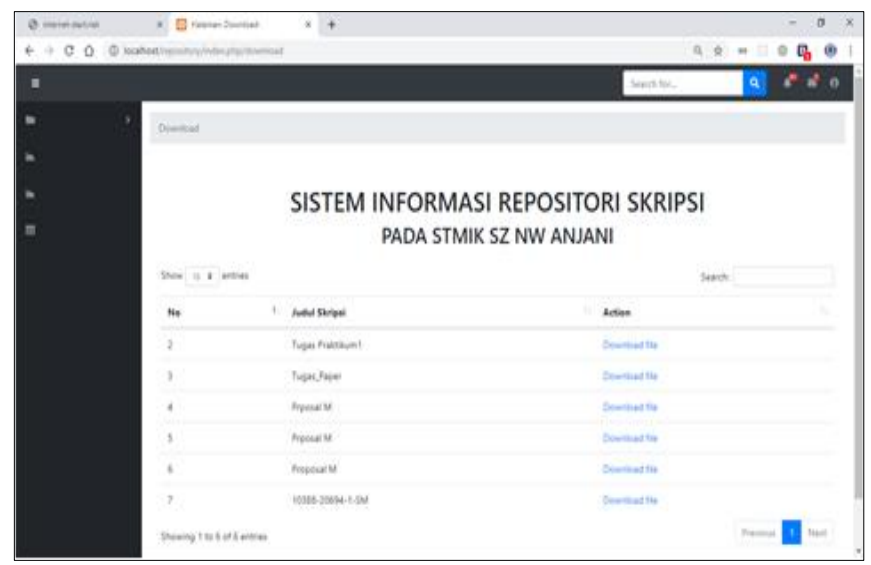

Gambar 17. Tampilan Halaman Download

\section{KESIMPULAN}

Berdasarkan penelitian yang dilakukan penulis, maka penulis menyimpulkan bahwa dalam pembuatan
Sistem Informasi Repository Skripsi Berbasis Web Pada STMIK SZ NW Anjani Lombok Timur adalah sebagai berikut :

Proses pengumpulan file skripsi yang berbentuk softcopy tidak lagi dilakukan secara konvensional yaitu file skripsi tinggal diupload lewat system dan pencarian skripsi bisa dilakukan dengan mudah dan bisa didownload, jadi bagi mahasiswa yang ingin mencari skripsi lama yang akan dijadikan sebagai refrensi terhadap suatu penelitian tidak perlu datng ke perpustakaan dan mencari di lemari arsip.

\section{UCAPAN TERIMKASIH}

Peneliti mengucapkan terimakAsih sebesar-besarnya kepada STMIK Syaikh Zainuddin NW Anjani dan semua pihak yang terlibat dalam penelitian ini sehingga penelitian ini dapat dipublikasikan.

\section{DAFTAR PUSTAKA}

[1] Wiyarsih. (2015). Pemanfaatan Koleksi Repository Perpustakaan Fakultas MIPA UGM Menggunakan EPrints. Berkala Ilmu Perpustakaan dan Informasi - Volume XI Nomor 2, Vol. 11 No. 2, 50-61.

[2] Hasugian, J. (2012). Internal Repository pada Perguruan Tinggi www.repository.usu.ac.id , 114.

[3] Amstrong, Michelle, 2013, Institutional repository management models that supportfaculty research dissemination, ww.emeraldinsight.com/1065075X.htm. [diakses 14 April, 2016]

[3] Hidayat F. (2017). Sistem Informasi Repository Skripsi Berbasis web pada FTKI Universitas Mulawarman. Makasar.

[4] Ainun N. (2015). Aplikasi Repository Skripsi Berbasis Android pada STMIK IBBI Medan. Medan. 